\title{
BACTERIAL INFECTION AND HOSPITAL INFECTION OF PATIENTS WITH INFLUENZA
}

\author{
E. J. L. Lowbury, M.A., D.M. \\ Bacteriologist, M.R.C. Industrial Injuries and Burns Research Unit, Birmingham Accident Hospital
}

THOUGH the atiology of influenza has for 30 years been the concern of virus workers, the secondary ravages of bacteria are still recognized to be a very important feature of the disease. I shall not attempt a wide survey of this subject, which would take me far outside my own province, but will consider the role of bacteria in patients admitted to hospital with influenza during recent outbreaks, with particular reference to prevention and treatment of secondary staphylococcal infections.

The importance of Staphylococcus aureus as a cause of pneumonia complicating influenza was reported from many sources during the Asian influenza epidemic of 1957. For instance, the Public Health Laboratory Service (1958) described the isolation of staphylococci from the lungs or sputum of $62 \%$ of 477 patients who died from pneumonia during the epidemic; the staphylococcus was held responsible for most of the deaths in young, healthy patients. Oswald, Shooter and Curwen (1958) reported a mortality of $28 \%$ in 155 cases of staphylococcal pneumonia complicating influenza, compared with a mortality of $12 \%$ in 145 patients with non-staphylococcal pneumonia; the high mortality of the staphylococcal cases appeared in all age-groups, whereas the mortality of the non-staphylococcal pneumonia was highest $(26 \%)$ in patients of 55 years of age or more, and low (o to $3 \%$ ) in the lower age groups. In most reports Staphylococcus aureus appeared to be the worst bacterial invader, though not necessarily the commonest; indeed Forbes (1958) found Staphylococcus aureus in only five out of 34 fatal cases with bacterial complications, both pneumococci and Streptococcus pyogenes being commoner.

The majority of staphylococcal infections are brought in, rather than acquired in hopital, by patients admitted with influenza (e.g. Public Health Laboratory Service, I958), but those who are admitted commonly acquire hospital strains of staphylococci. Oswald and his colleagues (1958) (Table $\mathrm{I}$ ) found a much higher proportion of staphylococci of hospital type resistant to penicillin and tetracycline in the sputum of influenzal pneumonia patients after they had been in the ward for several days than in their first days after admission; a relative increase of hospital phage types was shown in a similar comparison by
TABLE I

Sensitivities of Staphylococci From InFLUENZA Patients in Hospital with Staphylococcal. PNeUmonia

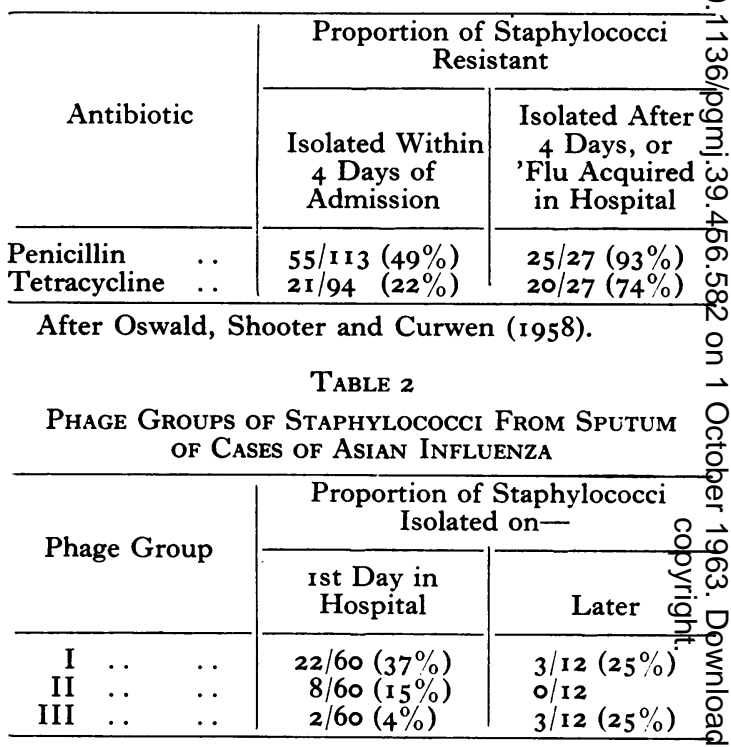

After Goslings, Mulder, Djadjadiningrat and Masure $\$$ (1959).

Goslings, Mulder, Djadjadiningrat and Masure (1959) (Table 2). A Combined Study Group in Dundee (1958) found that influenza patients. admitted to hospital had $H$. influenzae and pneumococci more often than staphylococci in. their sputum; after a few days, however, Staphy 3 lococcus aureus was commonly present and the other organisms were rarely found (Table 3 ) Outbreaks of infection by staphylococci of single phage pattern may occur-as found, for example, by Dr. Hearn at Dudley Road Hospitat during the epidemic of $195^{8}$.

\section{Sources and Control of Staphylococcal Infection}

An unusual finding was that of Goslings an $\mathscr{\alpha}^{N}$ his colleagues (1959) who reported 14/40 cases of staphylococcal influenzal pneumonia wite antecedent skin lesions caused by the same phag type of staphylococcus. A potential source of cross:infection during influenza epidemics which mas be more important is the respiratory tract of 
patients suffering from staphylococcal pneumonia or lung abscess (Shooter, Griffiths, Cook and Williams, I957; Mitchell, Shaw Dunn, Lees and Hedges, I96I). Open infections such as these must be considered the most prolific sources of virulent staphylococci. Other sources are (I) the patient's nasal, intestine and skin flora, and (2) staphylococci in the nose, skin, bedding and clothes of carriers (patients and staff) transferred on dust or droplets by air, or by contact with hands or fomites. Shooter, Girling, Matthias and Williams (1960) have found less evidence of cross-infection in medical than in surgical wards; but the presence of patients with open sepsis, of carriers who are also dispersers of virulent staphylococci (Hare and Thomas, 1956), and of highly susceptible individuals (e.g. those with influenza) increases the hazard of cross-infection.

The aseptic discipline of wards is designed to remove or disinfect the sources and reservoirs of pathogenic flora, to block their routes of transfer and to increase the patient's resistance. Recent studies have suggested the importance of the nose as a receptor and relay station of airborne hospital staphylococci (e.g. Williams and others, 1959). The hands of nurses and doctors are vectors of contact transfer recognized to be important since the time of Semmelweiss. I shall now say a little about the control of these channels of infection, which are possibly the most important in medical wards.

\section{Prevention of Nasal Colonization and Applications of Air Hygiene}

Various methods of antibiotic or antiseptic protection have been used; the commonest of these is a cream containing (for example) neomycin and chlorhexidine applied at intervals to the nostrils. Better results have been obtained with a nasal spray containing gramicidin and framycetin (Stratford, Rubbo, Christie and Dixson, 1960), with a methicillin ointment (Varga and White, I96I) and by spraying the ward air with methicillin (Elek and Fleming, 1960).

Another method, which should also protect the lower respiratory tract, is to nurse the patient in a ward, or preferably cubicle, ventilated with clean air from a plenum system or an air conditioner. At the Birmingham Accident Hospital we have installed in four twin-bedded cubicles air conditioning units ('Westair') which recirculate the air through filters and also admit a small proportion of outdoor air; the air conditioners have an output of about 300 cubic feet per minute. Daily settle plate counts and nasal swabs from patients were obtained in these and in four control cubicles with window ventilation. A preliminary examina-
TABLE 3

Bacteria Isolated From Sputum and Pharyngeal Swabs of Patients in Hospital with INFluenza

\begin{tabular}{l|c|c}
\hline \multirow{2}{*}{ Bacteria } & \multicolumn{2}{c}{$\begin{array}{c}\text { Proportion of Samples } \\
\text { Yielding Bacteria }\end{array}$} \\
\cline { 2 - 3 } & On Admission & $\begin{array}{c}\text { After 4 Days } \\
\text { and I Week }\end{array}$ \\
\hline Staphylococci $\ldots$ & $2 / 78(2.5 \%)$ & $24 / 71(34 \%)$ \\
Pneumococci $\ldots$ & $10 / 78(13 \%)$ & I/71 (1.4\%) \\
H. influenza $\ldots$ & $6 / 78(8 \%)$ & $2 / 71(2.8 \%)$ \\
\hline
\end{tabular}

After Combined Study Group (1958).

TABle 4

Presumptive Staphylococcus aureus and Total Organisms on Settle Plates Exposed FOR Six Hours

\begin{tabular}{|c|c|c|c|}
\hline \multirow[b]{2}{*}{ Cubicles } & \multicolumn{2}{|c|}{ Mean Viable Counts } & \multirow{2}{*}{$\begin{array}{l}\text { Observa- } \\
\text { tions }\end{array}$} \\
\hline & $\begin{array}{l}\text { 'Staph, } \\
\text { aureus' }\end{array}$ & $\begin{array}{c}\text { Total } \\
\text { Organisms }\end{array}$ & \\
\hline $\begin{array}{l}\text { Air conditioned } \\
\text { ('Westair' unit) }\end{array}$ & 32 & $4 \mathrm{I} 5$ & 206 \\
\hline Control $\ldots$ & 76 & 568 & 199 \\
\hline
\end{tabular}

TABLE 5

ACQuisition of TetracyCline-RESISTANT Staphylococci IN NARES

\begin{tabular}{|c|c|c|c|c|}
\hline \multirow{2}{*}{\multicolumn{3}{|c|}{$\begin{array}{l}\text { Days After } \\
\text { Admission }\end{array}$}} & \multicolumn{2}{|c|}{$\begin{array}{c}\text { Patients Acquiring Tetra- } \\
\text { cycline-resistant Staph. aureus }\end{array}$} \\
\hline & & & \multirow{2}{*}{$\begin{array}{c}\begin{array}{c}\text { In Air-condi- } \\
\text { tioned Cubicles } \\
\text { (36 Patients) }\end{array} \\
6(17 \%) \\
6(17 \%)\end{array}$} & \multirow{2}{*}{$\begin{array}{c}\begin{array}{c}\text { In Control } \\
\text { Cubicles } \\
\text { (31 Patients) }\end{array} \\
13(42 \%) \\
6(10 \%)\end{array}$} \\
\hline $\begin{array}{l}1-5 \\
6-10\end{array}$ & $\begin{array}{l}\cdots \\
\cdots\end{array}$ & $\begin{array}{l}\cdots \\
\cdots\end{array}$ & & \\
\hline $\begin{array}{l}\text { I I-20 } \\
\text { After } 20\end{array}$ & $\cdots$ & . & $3(8 \%)$ & 0 \\
\hline After 20 & & . & I $(3 \%)$ & 0 \\
\hline \multicolumn{2}{|c|}{ Total } & .. & $16(44 \%)$ & I9 $(61 \%)$ \\
\hline
\end{tabular}

tion (Table 4) shows that the air-conditioned cubicles had cleaner air than the control cubicles (mean presumptive Staphylococcus aureus counts in the former were less than half as great as they were in the latter). The noses of patients in the air conditioned cubicles acquired tetracyclineresistant 'hospital' staphylococci more slowly and less often than the noses of patients in the control cubicles (Table 5). These results are not brilliant, but the cubicles were in many ways inadequate and the patients (burns cases) were specially prone to infection. The effects of true plenum ventilation in specially designed wards would undoubtedly be greater (cf. Williams and others, 1962; Lack, Towers and Stevenson, 1962; Ayliffe and Beard, 1962). 
TABLE 6

Mean Percentage Survival of Hand Bacteria After Cleansing and Disinfection

\begin{tabular}{|c|c|c|c|c|c|}
\hline \multirow{2}{*}{$\begin{array}{c}\text { Cleasing or } \\
\text { Disinfection Method }\end{array}$} & \multicolumn{3}{|c|}{ Resident Bacteria } & \multicolumn{2}{|c|}{$\begin{array}{c}\text { Transient Bacteria } \\
\text { (Ps. aeruginosa) }\end{array}$} \\
\hline & $\begin{array}{c}\text { One } \\
\text { Applica- } \\
\text { tion }\end{array}$ & $\begin{array}{l}\text { Repeated } \\
\text { Applica- } \\
\text { tions }\end{array}$ & $\begin{array}{c}\text { No. of } \\
\text { Experi- } \\
\text { ments }\end{array}$ & $\begin{array}{l}\text { One } \\
\text { Applica- } \\
\text { tion }\end{array}$ & $\begin{array}{c}\text { No. of } \\
\text { Experi- } \\
\text { ments }\end{array}$ \\
\hline Soap and water .. & $56.3^{*}$ & $81 . I^{*}$ & 4 & $0.13 t$ & 8 \\
\hline 'pHisoHex' and water .. & $79.5^{*}$ & $2.0^{*}$ & 4 & $0.12 \dagger$ & 8 \\
\hline Chlorhexidine rinse & $38.6 \dagger$ & - & 4 & $0.004 \dagger$ & 8 \\
\hline
\end{tabular}

TABle 7

Mean Percentage of Transient Bacteria on Rubber Gloves and on Skin After Cleansing and Disinfection

\begin{tabular}{|c|c|c|c|c|}
\hline Organism & Treatment & Gloves & Skin & $\begin{array}{c}\text { No. of } \\
\text { Observa- } \\
\text { tions* }\end{array}$ \\
\hline E. coli & $\begin{array}{l}\text { Soap and water } \\
\text { Chlorhexidine rinse }\end{array}$ & $\stackrel{\circ}{\circ}$ & $\begin{array}{l}0.04 \\
0.015\end{array}$ & $\begin{array}{l}16 \\
16\end{array}$ \\
\hline Staph. aureus & $\begin{array}{l}\text { Soap and water } \\
\text { Chlorhexidine rinse }\end{array}$ & $\begin{array}{c}0.08 \\
0\end{array}$ & $\begin{array}{l}0.3 \\
0.005\end{array}$ & $\begin{array}{l}16 \\
16\end{array}$ \\
\hline $\begin{array}{r}\text { Ps. aeruginosa } \\
\text { (pyocyanea) }\end{array}$ & $\begin{array}{l}\text { Soap and water } \\
\text { Chlorhexidine rinse }\end{array}$ & $\begin{array}{c}0.0006 \\
0\end{array}$ & $\begin{array}{l}0.15 \\
0.08\end{array}$ & $\begin{array}{l}16 \\
16\end{array}$ \\
\hline
\end{tabular}

* Two experiments, each involving counts from 8 fingers. $† 0.5 \%$ in water.

\section{Disinfection of Hands}

In spite of Semmelweiss's demonstration in 1847 of the beneficial effects of rinsing with an antiseptic, soap and water has until recently been considered an adequate method for cleansing the hands of doctors and nurses in wards. Repeated use of hexachlorophane soap has been shown, in our hospital and elsewhere, to have great value in reducing the 'resident' flora (i.e. bacteria that grow on the skin, including in many subjects Staphylococcus aureus); a liquid soap or detergent cream is better in this respect than a solid soap, and an iodophor (e.g. 'Betadine' surgical scrub) is also very effective (Lowbury and Lilly, I960; Lowbury, Lilly and Bull, I963). Work in progress shows that the 'transient' flora (i.e. bacteria deposited on the skin but not growing there) can be removed much more effectively than the resident flora by detergent action or disinfection (Table 6). Rinsing for half a minute in aqueous chlorhexidine is somewhat more effective than simple detergent treatment for the same time, but both detergent and disinfectant action are more effective on a rubber glove than on the bare hand (Table 7).

One can only guess how useful these methods might be in reducing staphylococcal infection of influenza cases. The theoretical advantages of isolating patients, both the infected and those at risk, are obvious. A combination of methots as Gillespie and his colleagues have shown (19 $\overrightarrow{62})$ is likely to achieve much more than a single method of controlling the transfer of pathogenio organisms.

\section{Antibiotics and Chemotherapy Prophylaxis}

A controlled trial at a R.A.F. training camp. showed that a sulphonamide given to patients when admitted to hospital with a diagnosis of. influenza significantly shortened the course of illness (Martin, I96r). In severe cases complicated by staphylococcal pneumonia, however, antibiotię prophylaxis has been disappointing even when the infecting staphylococcus was sensitive to the agents used (Miller and Jay, 1962). The situation may of course, have improved with the recent develop ment of better antibiotics against the staphylo coccus. Martin and his colleagues stress the need for prompt effective chemotherapy as soon aS staphylococcal pneumonia is suspected (Martinf Kunin, Gottlieb and Finland, 1959).

\section{Therapy}

The lower mortality from influenzal pneumonia in the 1957 epidemic compared with the mortalito in 1918-19 is commonly attributed to the use of 
antibiotics; these, incidentally, may also have been a factor leading to the emergence of staphylococci and the retreat of other bacterial invaders.

During the epidemic of 1957 erythromycin, chloramphenicol and novobiocin were the most valuable anti-staphylococcal agents for use in hospital. Now we have fusidic acid and the penicillinase-tolerant penicillins (methicillin and cloxacillin). Fusidic acid has proved to have exceptional therapeutic activity in staphylococcal infections that respond poorly to other antibiotics, and its value in respiratory infections has been noted (Crawley, I962). The penicillinase-tolerant penicillins are active against virtually all staphylococci isolated in hospital, and resistance does not tend to emerge (e.g. Lowbury, Lilly, Miller, Cason and Jackson, I96r). These agents will probably increase the effectiveness of therapy for staphylococcal complications of influenza (including lung abscesses), though it is, perhaps, too much to hope that they will improve the prospects for survival in fulminating attacks.

\section{Comment and Summary}

I have offered these thoughts of a worker in one extensively studied field of hospital infection on the problems of another field which has been relatively neglected, because I believe that the same principles apply in each field. A variable but important proportion of the patients admitted to hospital with influenza acquire virulent staphylococci, which sometimes enhance the severity of their infection. Isolation of susceptible patients, air hygiene, and disinfection of the main vectors of staphylococci are methods found to reduce the sources and the transfer of staphylococci in surgical wards where an exceptional number of such infections are likely to occur. The newest antistaphylococcal antibiotics offer an advance in therapy; fusidic acid because of its high therapeutic activity and the penicillinase-tolerant penicillins because of the great rarity of resistant strains. The possible usefulness of these and other facilities require investigation when the next severe epidemic comes our way.

\section{REFERENCES}

Ayliffe, G. A. J., and BeArd, M. A. (1962): A System of Air Recirculation and Antibacterial Surface Treatment a Surgical Ward, $\mathcal{F}$. clin. Path., 15, 242.

Combined Study Group (1958): Some Aspects of the Recent Epidemic of Influenza in Dundee, Brit. med. Y., i, 908.

Crawley, F. E. (1962): Treatment of Respiratory Tract Infection. Symposium on Steroid Antibiotics, Royal Society of Medicine (Leo Laboratories Ltd.), p. 4.

Elek, S. D., and Fleming, P. C. (1960): A New Technique for the Control of Hospital Cross-infection, Lancet, ii, 569 .

Forbes, J. A. (1958): Severe Effects of Influenza Virus Infection, Med. F. Aust., 2, 75.

GILlespie, W. A. (1962): Progress in the Control of Hospital Cross-infection, Publ. Hlth (Lond.), 77, 44.

Goslings, W. R. O., Mulder, J., DJADJADININGRat, J., and Masurel, N. (I959): Staphylococcal Pneumonia in Influenza, in Relation to Antecedent Staphylococcal Skin Infection, Lancet, ii, 428.

HARE, R., and ThOMAS, C. G. A. (1956): The Transmission of Staphylococcus aureus, Brit. med. F., ii, 840.

LACK, C. H., Towers, A. G., and Stevenson, F. H. (1962): Cross-infection: Its Control in an Orthopædic Hospital by Means of a Cubicled Isolation Ward, Lancet, i, 1228 .

LowbuRY, E. J. L., and Lilly, H. A. (1960): Disinfection of the Hands of Surgeons and Nurses, Brit. med. F., i, 1445. , Miller, R. W. S., Cason, J. S., and JaCkson, D. M. (1961): Treatment of Infected Burns with Methicillin, Lancet, i, 1318.

$\overline{-},-$ and Bull, J. P. (1963): Disinfection of Hands: Removal of Resident Bacteria, Brit. med. F., i, r25 r.

Martin, C. M., Kunin, C. M., GotTliEb, L. S., and FinLand, M. (1959): Asian Influenza A in Boston, 1957-58: Severe Staphylococcal Pneumonia Complicating Influenza, Arch. intern. Med., ro3, 532.

MarTin, P. B. (I96I): A Trial of Sulphamethoxypyridazine (S.M.P.) in the Management of Influenza, f. Coll. gen. Pract., 4, 426.

Miller, W. E., and JAY, A. R. (196r): Staphylococcal Pneumonia in Influenza, Arch. intern. Med., ro9, 276.

Mitchell, A. A. B., DunN, R. I. Shaw, LeEs, T. W., and Hedges, C. K. (I96I): Staphylococcal Pulmonary Infection, Lancet, ii, 669.

Oswald, N. C., Shooter, R. A., and Curwen, M. P. (1958): Pneumonia Complicating Asian Influenza, Brit. med. Y., ii, 1305 .

Public Health Laboratory Service (1958): Deaths from Asian Influenza, 1957, Ibid., i, 915.

ShOoter, R. A., GriffithS, J. D., Cook, J., and Williams, R. E. O. (1957): Outbreak of Staphylococcal Infection in a Surgical Ward, Ibid., i, 433 .

- -, Girling, J. A., MatThias, J. O., and Williams, R. E. O. (1960): Staphylococcal Infection in a Medical Ward, Ibid., i, 1923 .

Stratford, B., Rubbo, S. D., Christie, R., and Dixson, S. (1960): Treatment of the Nasal Carrier of Staphylococcus aureus with Framycetin and Other Antibacterials, Lancet, ii, 1225.

VARGA, D. T., and WHITE, A. (196r): Suppression of Nasal, Skin and Aerial Staphylococci by Nasal Application of Methicillin, F. clin. Invest., 40, 2209.

Williams, R. E. O., Jevons, M. P., Shooter, R. A., Hunter, C. J. W., Girling, J. A., Griffiths, J. D., and TAYLOR, G. W." (I959): Nasal Staphylococci and Sepsis in Hospital Patients, Brit. med. F., ii, 658.

-, Noble, W. C., JEvons, M. P., LIDWELl, O. M., ShOoter, R. A., WhITE, R. G., ThorN, B. T., and TAYLOR, G. W. (1962): Isolation for the Control of Staphylococcal Infection in Surgical Wards, Ibid., ii, 275. 